\title{
The Presence of Mef (E) and Erm (B) Genes in Throat Samples of Children Infected with Streptococcus pyogenes
}

\section{Streptococcus pyogenes ile Enfekte Çocukların Boğaz Örneklerinde Mef (E) ve Erm (B) Genlerinin Varlığı}

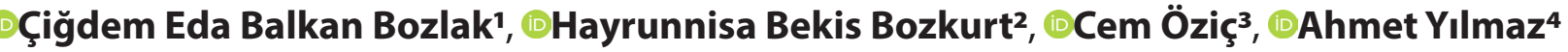

\author{
${ }^{1}$ Kafkas University, Faculty of Medisine, Department of Medical Microbiology, Kars, Turkey \\ 2'stanbul Medeniyet University, Faculty of Medicine, Department of Pediatrics, Kars, Turkey \\ ${ }^{3}$ Kafkas University, Medical Faculty, Department of Molecular Biology, Kars, Turkey \\ ${ }^{4}$ Ataturk University, Vocational School of Health, Department of Medical Laboratory Techniques, Erzurum, Turkey
}

\begin{abstract}
Aim: Antibiotic resistance studies about the Streptococcus have a great importance for the treatment of especially child throat infections in terms of public health and rational antibiotic use. For this purpose, we aimed to identify the macrolide resistance genes mef(E) and erm(B).

Material and Method: The throat culture samples taken from 51 children presenting to the hospital with the complaint of sore throat were evaluated in the laboratory, and S. pyogenes was diagnosed using tests; gram staining, catalase, bacitracin and PYR. Susceptibility profile was determined with the Kirby-Bauer diskdiffusion method and minimum inhibitor concentration(MICs) of erythromycin and clindamycin was determined by VTEC 2 System.

Results: S. pyogenes was possible macrolide resistance genes of mef(E) and erm(B) was determined by PCR. Macrolide resistance in $S$. pyogenes are determined in 51 pateients as follows; benzylpenicillin $0 \%$, erytromycin $74.5 \%$, clindamycin $31.4 \%$. In patients with $S$. pyogenes, the genetic determinants of macrolide resistance $\operatorname{mef}(E)$ and erm(B) genes was investigated with the PCR method using primers specific to each gene. Total of $48 \%$ of the isolates $(n=24)$ were positive for erm $(B), 10 \%(n=5)$ for mef(E), in $42 \%(n=21)$ of the isolates both genes were detected.

Conclusion: When the anamnesis of these patients was examined, it was determined that there were patients that frequently presented to the hospital with throat infections and experienced re-infection within a few weeks after receiving treatment. Due to the threat of antimicrobial resistance in S. pyogenes, especially in children, national and city surveillance studies are needed to detect resistance. This should be supported by our research, new hypotheses and studies that are open to development.
\end{abstract}

Keywords: Resistance genes, PCR, Streptococcus pyogenes, molecular epidemiolgy
Öz

Amaç: Streptococcus ile ilgili yapılan antibiyotik direnç çalışmaları, özellikle çocuk boğaz enfeksiyonlarının tedavisinde halk sağlığı ve akılcı antibiyotik kullanımı açısından büyük önem taşımaktadır. Biz de çalışmamızda bu amaçla makrolid direnç genleri mef (E) ve erm (B) 'yl tanımlamayı amaçladık.

Gereç ve Yöntem: Boğaz ağrısı şikayeti ile hastaneye başvuran 51 çocuktan alınan boğaz kültürü örnekleri laboratuvarda değerlendirildi ve gram boyama, katalaz, basitrasin ve PYR testleri ile S. pyogenes tanısı konuldu. Duyarlıık profili Kirby-Bauer disk difüzyon yöntemi ile ve eritromisin ile klindamisinin minimum inhibitör konsantrasyonu (MIK), VITEK 2 Sistemi ile saptandı.

Bulgular: S. pyogenes, mef (E) ve erm (B) 'nin olası makrolid direnç genleri PCR ile belirlendi S. pyogenes'te ki makrolid direnci 51 hastada aşağıdaki gibi saptandı; benzilpenisilin \%0, eritromisin \%74,5, klindamisin \%31,4. S. pyogenes hastalarında makrolid direnci mef (E) ve erm (B) genlerinin genetik belirteçleri her gene özel primerler kullanılarak PCR yöntemi ile araştırıldı. İzolatların toplam \%48'i ( $n=24)$ erm (B) için pozitif, \%10'u ( $n=5)$ mef (E) için pozitif, \%42'sinde $(n=21)$ her iki gen birlikte tespit edildi.

Sonuç: Çalışmamızın sonuçlarına göre makrolid direnç genleri pozitif hastaların anamnezleri incelendiğinde, hastaneye sık sık boğaz enfeksiyonu ile başvuran ve tedavi aldıktan sonraki birkaç hafta içinde tekrar enfeksiyon yaşayan hastaların olduğu belirlendi. S. pyogenes'te özellikle çocuklarda antimikrobiyal direnç tehdidi nedeniyle, direnci saptamak için ulusal ve şehir sürveyans çalışmalarına ihtiyaç vardır. Bu nedenle araştırmamız, geliştirmeye açık yeni hipotezler ve çalışmalarla desteklenmelidir.

Anahtar Kelimeler: Direnç genleri, PCR, Streptococcus pyogenes, moleküler epidemiyoloji 


\section{INTRODUCTION}

Streptococcus pyogenes is beta hemolytic, gram-positive bacteria in Group A streptococcus (GAS) according to the Lancefield classification and caused several infections for centuries. Although it is associated with a wide range of diseases that can progress from skin infections to sepsis, it is largely known as being the most common infectious agent in throat and upper respiratory tract infections. [1] In addition to causing acute diseases, it can also lead to serious complications, such as acute rheumatic fever and glomerulonephritis. Especially in newborns, it is observed that the frequency of infection increases after the gradual decrease of immunity acquired through breast milk. In school children (aged 5-15 years), the incidence of GAS pharyngitis is not negligible, with the presence of GAS being asymptomatic in about $15-20 \%$ of this age group. ${ }^{[2]}$ It is very important to detect bacteria to eradicate the disease and prevent associated complications with antibiotic treatment, as well as stopping its spread, especially in environments with a high contagion risk, such as schools and nurseries. ${ }^{[3,4]}$

For many years, macrolides have been used as a second option when there is no response from penicillin treatment against gram-positive bacteria. Despite this situation being commonly observed in practice, there is some studies conclusively reporting that streptococci have reduced susceptibility to beta lactam antibiotics. ${ }^{[5]}$ In some clinical studies, it has been observed that $30 \%$ of the patients did not respond to penicillin treatment in tonsillopharyngitis caused by GAS. ${ }^{[6]}$ This situation is considered to occur as a result of the evolution of bacteria, especially in terms of their mechanisms of escape from antibiotics. ${ }^{[6]}$ Macrolides, which are used as the second treatment choice in patients, are also globally becoming increasingly resistant to antibiotics. ${ }^{[7]}$ In our study we aim to find some genes which has roles in macrolide resistance. For this reason, it is of great importance to detect virulence factors, antibiotic escape mechanisms, microorganism subtypes, and resistant genes of streptococcus infections. As is known, M protein is among the main virulence factors in GAS, and strains detected with the use of $M$ antisera in species differentiation are called 'M serotypes'. However, today, it is known that there are streptococcal groups that cannot be defined based on $M$ protein alone. For this reason, genotype determination and especially 16s rRNA are used in the differentiation of streptococci. ${ }^{[8]}$ According to the conducted studies, there is often unnecessary antibiotic use without a culture analysis in infections for which GAS bacteria are possibly responsible. ${ }^{[9]}$ Despite seeming simple, it is actually very difficult to eradicate GAS infections considering their clinical implications while also avoiding unnecessary antibiotherapy and preventing resistance to antibiotics. ${ }^{[10]}$ To date, there is no vaccine for this bacterium, and this presents a serious risk in certain conditions of neonatal sepsis and infant mortality. ${ }^{[10]}$
This study has recently been conducted to examine $S$. pyogenes macrolide resistance and resistant genes taken from children admitted to our hospital with sore throat. In case of penicillin allergy or treatment response problems other options are macrolides, beta-lactams, clindamycin or oral cephalosporins are used. Our aims were to find $S$. pyogenes antibiotic resistance and investigate the mef $(E)$ and erm (B) genes which cause macrolide resistance.

\section{MATERIAL AND METHOD}

\section{Collection of Samples, Identification of S. pyogenes and Susceptibility}

Throat cultures of 78 patients who applied to the Kafkas University Research and Application Hospital outpatient clinic with a complaint of sore throat were taken by clinicans and sent to the microbiology laboratory. The samples were first inoculated onto blood agar, put bacitracin disc and then kept in an etuve for 24 hours, PYR test was applied to beta hemolytic colonies. All streptococcus suspected colonies adjusted to 0.5 MacFarland standart in indol broth and were seeded on Muller Hinton Agar. All patients with S.pyogenes detected were included to the study. Penicillin G (benzylpenicillin), Eritromycin, Clindamycin disks were placed on the medium. Susceptibility of cephalosporins and carbapenems is inferred to the benzypenicillin in EUCAST 2020. The susceptibility limits of antibiotics according to the Eucast criteria are given in Table 2. Minimum inhibitor concentration(MICs) of erythromycin and clindamycin was determined by VTEC 2 (BioMerieux, France). Bacteria stored at $-80^{\circ} \mathrm{C}$ for genetic examination. ${ }^{[1]]}$

\section{Genomic DNA Isolation Protocol}

The samples were placed into eppendorf tubes, to which

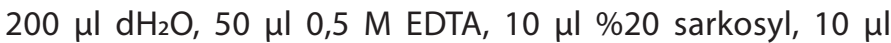
proteinase $\mathrm{K}(10 \mathrm{mg} / \mathrm{ml}), 10 \mu \mathrm{l} 1 \mathrm{M}$ Tris- $\mathrm{HCl}(\mathrm{pH}: 8)$, and $5 \mu \mathrm{l}$ $5 \mathrm{M} \mathrm{NaCl}$ were added. The mixture was vortexed for $5 \mathrm{~min}$ and kept in a water bath set at $65^{\circ} \mathrm{C}$ for $30 \mathrm{~min}$. During this period, the mixture was vortexed every 10 minutes. Phenol: chloroform: isoamyl alcohol (25:24:1) was added to the cell suspension. It was then centrifuged at 13,000 rpm for $5 \mathrm{~min}$. The supernatant layer was removed with a Pasteur pipette (or a 1,000 $\mu \mathrm{l}$ micropipette the tip of which was cut with a razor blade) and transferred to a new tube. The phenol: chloroform: isoamyl alcohol procedure was performed three times as described above. In each step, the supernatant was removed from the products obtained at the end of centrifugation and transferred to a clean eppendorf tube, to which $3 \mathrm{M} \mathrm{NaAc}$ at $1 / 10$ of its volume and absolute ethanol at two times of its volume were added, and this mixture was kept overnight at $-20^{\circ} \mathrm{C}$. At the end of this period, the sample was centrifuged at 13,000 rpm for $10 \mathrm{~min}$. The supernatant was removed, and the

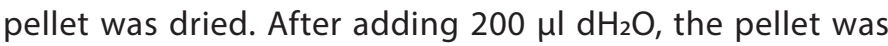
thawed and 0.3 M NaOAc and $440 \mu$ lethanol were added 
at $1 / 10$ volume and kept overnight at $-20^{\circ} \mathrm{C}$. At the end of this period, the sample was centrifuged at $13,000 \mathrm{rpm}$ for $5 \mathrm{~min}$. The supernatant was removed, and the pellet was allowed to dry. After drying, the pellet was thawed

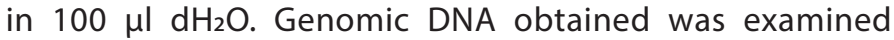
for quality, RNA contamination and integrity according to the spectrophotometric measurement first, followed by imaging in $0.8 \%$ agarose gel. ${ }^{[12]}$

\section{Gene Sequences used for the Detection of Resistance Genes}

In this study, primers containing the following gene sequences were used. ${ }^{[13]}$

\section{erm (B): F5'-ATTGGAACAGGTAAAGGGC-3' and R5'-GAACATCTGTGGTATGGCG-3' \\ mef (E): F5'-GGGAGATGAAAAGAAGGAGT-3' and R5'-TAAAATGGCACCGAAAG-3'.}

\section{Genomic DNA Replication}

Genomic DNA was used as source DNA in the PCR reaction. The $P C R$ reaction was established with macrolid resistant genes specific ( $F$ and $R$ ) primers. A solution containing $2.5 \mu \mathrm{l} 10 \mathrm{X}$ buffer, $2.5 \mu \mathrm{l} 25 \mathrm{mM} \mathrm{MgCl} 2,2 \mu \mathrm{l} 2.5 \mu \mathrm{M}$ dNTP mixtures, $2.5 \mu \mathrm{F}, 2.5 \mu \mathrm{l}, 0.5 \mu \mathrm{l}$ genomic DNA, and $0.2 \mu \mathrm{l}$ Taq DNA polymerase enzyme $(5 \mathrm{u} / \mu \mathrm{l})$ was completed to

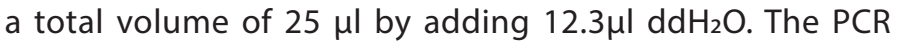
program used for products was as follows: at $94^{\circ} \mathrm{C}$ for $2 \mathrm{~min}$, at $94^{\circ} \mathrm{C}$ for $1 \mathrm{~min}$, at $55^{\circ} \mathrm{C}$ for $1 \mathrm{~min}$, at $72^{\circ} \mathrm{C}$ for $1 \mathrm{~min}$, at $72^{\circ} \mathrm{C}$ for $4 \mathrm{~min}$, and at $4^{\circ} \mathrm{C}$ for $\infty$.

\section{Agarose Gel Analysis And Gel Imaging}

The DNA fragments run in the agarose gel were checked in a UVP transilluminator device, and the data were recorded using a UV-photometer gel documentation device (UviTec). The study permit was obtained from "Kafkas University, Faculty of Medicine Ethics Board with the decision dated 25.04.2018 and numbered 80576354-050-99

\section{RESULTS}

\section{Antibiotic Susceptibility Results}

With Kirby Bauer disc diffusion method; The antibiotic resistance rates of $S$. pyogenes strains are determined in 51 pateients as follows; benzylpenicillin \%0, erytromycin $74.5 \%$, clindamycin $31.4 \%$. In order to determine the macrolide resistance in more detail, the MICs of the $S$. pyogenes strains were examined with VTEC 2 (bioMerieux) and minimum inhibitory concentrations (MIC) were noted. Clinical breakpoints - breakpoints and guidance EUCAST 2020 was used for determine the resistance. Samples which were resistant to two or more antibiotics were considered as multi drug resistant. Demographic distrubution of patients are in Table $\mathbf{1}$ and Macrolide resistance in Table $\mathbf{2}$.
Table 1. Demographic Details of Patients

\begin{tabular}{llcc} 
Age & Gender & $\begin{array}{c}\text { Multidrug Resistant } \\
\text { Strains }\end{array}$ & $\begin{array}{c}\text { Non-Multidrug Resistant } \\
\text { Strains }\end{array}$ \\
\hline \multirow{2}{*}{ (0-18) } & Male $(\mathrm{n}: 39)$ & $\mathrm{N}: 6$ & $\mathrm{~N}: 33$ \\
& Female $(\mathrm{n}: 12)$ & $\mathrm{N}: 3$ & $\mathrm{~N}: 9$ \\
\hline
\end{tabular}

Table 2. Distrubution of Macrolide Resistance and Sensitivity in 51 Patients Throat Sample.

\begin{tabular}{lccc}
\hline Antibiotic & $\begin{array}{c}\text { Sensitive/ } \\
\text { Resistance }\end{array}$ & $\begin{array}{c}\text { Number of Resistance } \\
\text { Patients (n) }\end{array}$ & Percentage \\
\hline Erytromycin & Resistant & 38 & $74.5 \%$ \\
Clindamycin & Resistant & 16 & $31.4 \%$ \\
$\begin{array}{c}\text { Erytromycin } \\
+\end{array}$ & Resistant & 9 & $17.6 \%$ \\
$\begin{array}{l}\text { Clindamycin } \\
\text { Erytromycin } \\
+\end{array}$ & Sensitive & & \\
\begin{tabular}{l} 
Clindamycin \\
\hline
\end{tabular} & & 6 & $11.8 \%$ \\
\hline
\end{tabular}

Antibiotic susceptibility was identified in 51 patients with $S$. pyogenes and their resistant genes are on Table 3 . Samples are taken from pediatric patients incoming to our hospital with sore throat.

\section{Resistant Gene Regions}

In this study, we aimed to determine the macrolid resistance of the identified S. pyogenes species. The genetic determinants of macrolide resistance were investigated with the PCR method using primers specific to each of the mef (E) and erm (B) genes. Total of $48 \%$ of the isolates $(n=24)$ were positive for erm (B), 10\% ( $n=5)$ for mef $(E)$, in $42 \%(n=21)$ of the isolates both genes were detected. Within the scope of the study, it was observed that the expression levels of these genes decreased in some patients $(n=5)$, and this was considered to be the reason for the lack of response to macrolides in these cases (Figure 1).

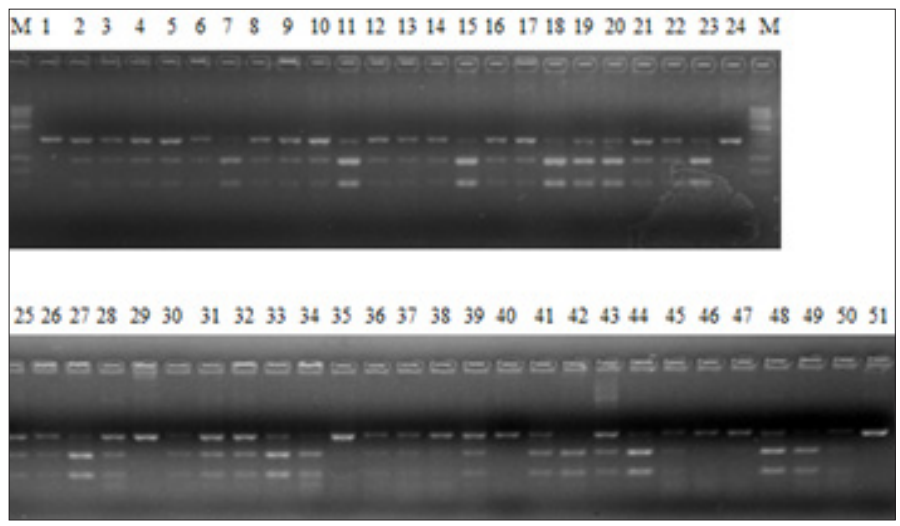

Figure 1. The macrolid resistant genes of the erm (B), mef (E) and erm (B)+mef (E) genes. Ladder 1-51 healty patients. M: 50-1000 bp ladder (Bio Basic GM345). The DNA fragments were separated in $2 \%$ agarose gel and visualized with ethidium bromide. 
Table 3. Antibiotic and macrolid genes resistant of patients with S. pyogenes

\begin{tabular}{|c|c|c|c|c|c|c|c|}
\hline \multirow{2}{*}{ Patients/ender } & \multicolumn{2}{|c|}{ Erytromycin*** } & \multicolumn{2}{|c|}{ Clindamycin } & \multirow{2}{*}{$\begin{array}{l}\text { Genes } \\
\text { erm (B) }\end{array}$} & \multirow{2}{*}{$\begin{array}{l}\text { Genes } \\
\text { mef (E) }\end{array}$} & \multirow{2}{*}{$\begin{array}{c}\text { Genes } \\
\text { erm (B)+ mef (E) }\end{array}$} \\
\hline & ${ }^{*} \mathrm{MIC}(\mathrm{S} / \mathrm{R}) \mathrm{mg} / \mathrm{L}$ & **KB (S/R) mm & MIC (S/R) mg/L & KB (S/R) mm & & & \\
\hline $1 \mathrm{~F}$ & $>0.05 \mathrm{~S}$ & $22 \mathrm{~S}$ & $>0.01 \mathrm{~S}$ & $18 \mathrm{~S}$ & + & - & - \\
\hline $2 M$ & $>0.5 \mathrm{R}$ & $17 \mathrm{R}$ & $>0.15 \mathrm{~S}$ & $20 \mathrm{~S}$ & + & - & - \\
\hline $3 M$ & $>0.75 \mathrm{R}$ & $16 \mathrm{R}$ & $>0.05 \mathrm{~S}$ & $23 \mathrm{~S}$ & + & - & - \\
\hline $4 M$ & $>1.5 \mathrm{R}$ & $14 \mathrm{R}$ & $>0.25 \mathrm{~S}$ & $22 \mathrm{~S}$ & - & - & + \\
\hline $5 \mathrm{M}$ & $>1.5 \mathrm{R}$ & $13 R$ & $>0.1 \mathrm{~S}$ & $20 \mathrm{~S}$ & + & - & - \\
\hline $6 \mathrm{~F}$ & $>0.55 \mathrm{R}$ & $17 \mathrm{R}$ & $>0.25 \mathrm{~S}$ & $23 \mathrm{~S}$ & - & - & + \\
\hline $7 \mathrm{M}$ & $>0.25 \mathrm{~S}$ & $22 \mathrm{~S}$ & $>0.5 \mathrm{R}$ & $16 \mathrm{R}$ & + & - & - \\
\hline $8 M$ & $>0.5 \mathrm{R}$ & $16 \mathrm{R}$ & $>0.5 \mathrm{R}$ & $14 R$ & - & - & + \\
\hline $9 M$ & $>0.5 \mathrm{R}$ & $17 \mathrm{R}$ & $>0.05 \mathrm{~S}$ & $20 \mathrm{~S}$ & - & + & - \\
\hline $10 M$ & $>0.01 \mathrm{~S}$ & $23 \mathrm{~S}$ & $>0.25 \mathrm{~S}$ & $22 \mathrm{~S}$ & + & - & - \\
\hline $11 \mathrm{~F}$ & $>2.25 \mathrm{R}$ & $10 \mathrm{R}$ & $>1.5 \mathrm{R}$ & $14 \mathrm{R}$ & - & - & + \\
\hline $12 \mathrm{M}$ & $>0.5 \mathrm{R}$ & $15 \mathrm{R}$ & $>0.25 \mathrm{~S}$ & $22 \mathrm{~S}$ & + & - & - \\
\hline $13 \mathrm{~F}$ & $>0.5 \mathrm{R}$ & $14 \mathrm{R}$ & $>0.05 \mathrm{~S}$ & $20 \mathrm{~S}$ & + & - & - \\
\hline $14 M$ & $>1.5 \mathrm{R}$ & $15 \mathrm{R}$ & $>0.25 \mathrm{~S}$ & $22 \mathrm{~S}$ & - & - & + \\
\hline $15 \mathrm{~F}$ & $>0.75 \mathrm{R}$ & $17 \mathrm{R}$ & $>0.2 \mathrm{~S}$ & $20 \mathrm{~S}$ & + & - & - \\
\hline $16 \mathrm{M}$ & $>250 \mathrm{R}$ & $15 R$ & $>1.25 \mathrm{R}$ & $15 R$ & - & - & + \\
\hline $17 \mathrm{M}$ & $>0.5 \mathrm{R}$ & $16 \mathrm{R}$ & $>0.2 \mathrm{~S}$ & $22 \mathrm{~S}$ & + & - & - \\
\hline $18 \mathrm{M}$ & $>1.5 \mathrm{R}$ & $16 \mathrm{R}$ & $>0.05 \mathrm{~S}$ & $23 \mathrm{~S}$ & - & + & - \\
\hline $19 \mathrm{M}$ & $>0.05 \mathrm{~S}$ & $24 \mathrm{~S}$ & $>0.5 \mathrm{R}$ & $16 \mathrm{R}$ & + & - & - \\
\hline $20 M$ & $>0.05 \mathrm{~S}$ & $22 \mathrm{~S}$ & $>0.15 \mathrm{~S}$ & $20 \mathrm{~S}$ & - & - & + \\
\hline $21 \mathrm{M}$ & $>0.5 \mathrm{R}$ & $14 \mathrm{R}$ & $>0.05 \mathrm{~S}$ & $20 \mathrm{~S}$ & + & - & - \\
\hline $22 \mathrm{~F}$ & $>1.5 \mathrm{R}$ & $13 R$ & $>0.25 \mathrm{~S}$ & $22 \mathrm{~S}$ & + & - & - \\
\hline $23 \mathrm{M}$ & $>2.5 \mathrm{R}$ & $15 \mathrm{R}$ & $>1.75 \mathrm{R}$ & $16 R$ & - & - & + \\
\hline $24 \mathrm{M}$ & $>0.5 \mathrm{R}$ & $15 R$ & $>0.25 \mathrm{~S}$ & $22 \mathrm{~S}$ & - & + & \\
\hline $25 \mathrm{~F}$ & $>0.5 \mathrm{R}$ & $14 \mathrm{R}$ & $>0.05 \mathrm{~S}$ & $24 S$ & - & - & + \\
\hline $26 \mathrm{M}$ & $>0.25 \mathrm{~S}$ & $23 \mathrm{~S}$ & $>0.05 \mathrm{~S}$ & $22 \mathrm{~S}$ & + & - & - \\
\hline $27 \mathrm{M}$ & $>0.075 \mathrm{~S}$ & $22 \mathrm{~S}$ & $>0.5 \mathrm{R}$ & $16 \mathrm{R}$ & - & - & + \\
\hline $28 \mathrm{~F}$ & $>1 \mathrm{R}$ & $11 \mathrm{R}$ & $>0.75 \mathrm{R}$ & $15 R$ & - & - & + \\
\hline $29 M$ & $>0.75 \mathrm{R}$ & $15 R$ & $>0.05 \mathrm{~S}$ & $24 \mathrm{~S}$ & + & - & - \\
\hline $30 \mathrm{M}$ & $>1.5 \mathrm{R}$ & $13 R$ & $>0.25 \mathrm{~S}$ & $22 \mathrm{~S}$ & + & - & - \\
\hline $31 \mathrm{M}$ & $>0.075 \mathrm{~S}$ & $24 \mathrm{~S}$ & $>0.1 \mathrm{R}$ & $14 R$ & - & - & + \\
\hline $32 \mathrm{~F}$ & $>0.25 \mathrm{~S}$ & $23 \mathrm{~S}$ & $>0.25 \mathrm{R}$ & $16 \mathrm{R}$ & + & - & - \\
\hline $33 \mathrm{M}$ & $>2.00 \mathrm{R}$ & $10 \mathrm{R}$ & $>1.05 \mathrm{R}$ & $12 \mathrm{R}$ & - & - & + \\
\hline $34 \mathrm{M}$ & $>5.25 \mathrm{R}$ & $6 R$ & $>2.25 \mathrm{R}$ & $10 \mathrm{R}$ & - & - & + \\
\hline $35 \mathrm{M}$ & $>0.02 \mathrm{~S}$ & $22 \mathrm{~S}$ & $>0.5 \mathrm{R}$ & $14 R$ & + & - & - \\
\hline $36 \mathrm{~F}$ & $>0.75 \mathrm{R}$ & $11 \mathrm{R}$ & $>0.05 \mathrm{~S}$ & $21 \mathrm{~S}$ & - & + & - \\
\hline $37 \mathrm{M}$ & $>1.5 \mathrm{R}$ & $1 \mathrm{R}$ & $>0.25 \mathrm{~S}$ & $22 \mathrm{~S}$ & - & - & + \\
\hline $38 \mathrm{~F}$ & $>1.25 \mathrm{R}$ & $11 \mathrm{R}$ & $>1 R$ & $13 R$ & - & - & + \\
\hline $39 M$ & $>1.0 \mathrm{R}$ & $14 R$ & $>0.005 \mathrm{~S}$ & $25 \mathrm{~S}$ & + & - & - \\
\hline $40 \mathrm{M}$ & $>0.5 \mathrm{R}$ & $15.5 \mathrm{R}$ & $>0.25 \mathrm{~S}$ & $22 \mathrm{~S}$ & - & - & + \\
\hline $41 \mathrm{M}$ & $>0.25 \mathrm{~S}$ & $22 \mathrm{~S}$ & $>0.01 \mathrm{~S}$ & $18 \mathrm{~S}$ & - & + & \\
\hline $42 \mathrm{~F}$ & $>0.05 \mathrm{~S}$ & $23 \mathrm{~S}$ & $>0.5 \mathrm{R}$ & $16 \mathrm{R}$ & - & - & + \\
\hline $43 M$ & $>0.75 \mathrm{R}$ & $15 \mathrm{R}$ & $>0.05 \mathrm{~S}$ & $24 \mathrm{~S}$ & + & - & - \\
\hline $44 \mathrm{M}$ & $>0.5 \mathrm{R}$ & $17 \mathrm{R}$ & $>0.05 \mathrm{~S}$ & $23 \mathrm{~S}$ & + & - & - \\
\hline $45 \mathrm{M}$ & $>1.0 \mathrm{R}$ & $14 R$ & $>0.25 \mathrm{~S}$ & $22 \mathrm{~S}$ & - & - & + \\
\hline $46 \mathrm{M}$ & $>0.5 \mathrm{R}$ & $16 \mathrm{R}$ & $>0.05 \mathrm{~S}$ & $24 S$ & + & - & - \\
\hline $47 \mathrm{M}$ & $>1 \mathrm{R}$ & $12 \mathrm{R}$ & $>25 \mathrm{R}$ & $13 R$ & - & - & + \\
\hline $48 \mathrm{M}$ & $>1.0 \mathrm{R}$ & $14 R$ & $>0.25 \mathrm{~S}$ & $22.5 \mathrm{~S}$ & + & - & - \\
\hline $49 \mathrm{M}$ & $>0.5 \mathrm{R}$ & $16 \mathrm{R}$ & $>0.05 \mathrm{~S}$ & $24 \mathrm{~S}$ & + & - & - \\
\hline $50 \mathrm{M}$ & $>0.05 \mathrm{~S}$ & $22 \mathrm{~S}$ & $>0.005 \mathrm{~S}$ & $18 \mathrm{~S}$ & - & - & + \\
\hline $51 \mathrm{M}$ & $>0.5 \mathrm{R}$ & $17 \mathrm{R}$ & $>0.15 \mathrm{~S}$ & $20 \mathrm{~S}$ & + & - & - \\
\hline
\end{tabular}




\section{DISCUSSION}

S. pyogenes is the most common cause of throat infections among bacteria. Both acute and chronic forms of GAS infections can be seen at the age of three and over; therefore, they are diseases that frequently occur in a wide age group. ${ }^{[15]}$ Contagion occurs with close contact through infected droplets. In addition to domestic transmission, other environments with a high risk of transmission include public areas, such as schools, barracks, and kindergartens. ${ }^{[16]}$ Especially in acute forms, the disease usually spontaneously regresses in a week without the addition of antibiotics to treatment. However, in the presence of severe complications, including acute rheumatic fever and glomerulonephritis, it is recommended to start penicillin treatment without waiting for the culture result, and Hanage et al. stated that resistant strains were developing in patients that did not respond to treatment. ${ }^{[17]}$ Since studies began to be conducted in 1985, growing experience in clinical practice indicates that some patients have resistance against penicillin treatment and that it does not seem beneficial in eradicating Group B streptococci, but this situation cannot be proven in vitro in real life. ${ }^{[18]}$ Examining the results of some antibiotic resistance studies across the world, erythromycin-resistant S. pyogenes was found in $35 \%$ of the children admitted to hospital with throat infections in Italy. ${ }^{[19]}$ A study from Turkey by Dundar and friends in 2010, a total of 127 S. pyogenes clinical isolates were tested. $11(9 \%)$ isolates were resistant to erythromycin, and $23(18 \%)$ isolates were resistant to tetracycline. ${ }^{[20]}$ In our study, the rate of erythromycin resistance was determined as $74.5 \%$. It is also seen that there is gradually increasing macrolide resistance inversely proportional to age, especially among pediatric patients. Lu and friends study in macrolideresistance S. pyogenes isolates in China from 2009 to 2016, they found S. pyogenes isolates were susceptible to penicillin, ampicillin, cefotaxime, and vancomycin and were resistant to erythromycin 131 (93.5\%), clindamycin 132 (94.2\%), and tetracycline 121 (86.4\%), respectively. ${ }^{[21]}$ In our study resistance rates were found erytromycin $74.5 \%$, clindamycin $31.4 \%$, studies show that resistance rates are increasing in the pediatric age group, but when viewed all over the world, it is not as aggressive as in adults, at least in our region. Examining the in vitro effects of antibiotics, we obtained similar results to the literature concerning the distribution and antibiotic susceptibility of $S$. pyogenes strains in the pediatric group. [22] In a study upon GAS isolates from ten European centers; Bulgaria, Croatia, the Czech Republic, Hungary, Latvia, Lithuania, Poland, Romania, Slovakia and Slovenia, detected erm (A) genetic elements of resistance in $2 \%$ and mef $(A)$ in $3 \%$, but erm (B) was not reported during the years of 20002001 and study is not including Turkey isolates. ${ }^{[23]}$ In our study total of $48 \%$ of the isolates $(n=24)$ were positive for erm (B), $10 \%(n=5)$ for mef $(E)$, in $42 \%(n=21)$ of the isolates both genes were detected. According to our knowledge, this is the first study in which S. pyogenes resistance and genes distribution is investigated in east part of Turkey.
When the distribution of resistance among our patients was examined, it was observed that resistance to Clindamycin in S. pyogenes was $31.4 \%$. In a study undertaken by Oryaşin et al., it was reported that the erm B and erm TR genes might have this activity of resistance. ${ }^{[2]}$ In our study clindamycin resistant four patients have erm (B) resistance.

Macrolides are used as a second option in patients in case of penicillin allergy or patients who do not respond to penicillin treatment. ${ }^{[25]}$ In an animal study by Samir et al., penicillin and macrolide-resistant S. pyogenes was identified, and erm (B), one of the resistance genes, was detected in the whole sample. The authors commented that this situation posed a risk of bacterial transmission to humans through children that are in close contact with animals. ${ }^{[26]}$ Total of $48 \%$ of the isolates $(n=24)$ were positive for erm (B), $10 \%$ $(n=5)$ for mef $(E)$, in $42 \%(n=21)$ of the isolates both genes were detected. Like our study erm(B) is the most frequently reported resistance gene countries such as Germany, Turkey and France. ${ }^{[20,27,28]}$ According to the hospital records, our constituted a population that presented to the hospital several times a year due to throat infections. It was observed that the patients in this group did not respond well to macrolide treatment. It is considered that S. pyogenes strains, which have not yet received as much global attention as they require, may gradually become more resistant, to the extent of being described as super-resistant in future. ${ }^{[17]}$

Some studies have also mentioned the necessity to use secondary treatment options in throat infections that do not respond to antibiotic treatment and emphasized how wrong it was to prescribe medicine for pediatric and adult patients by considering their symptoms alone. ${ }^{[29]}$ In the vast majority of studies, macrolide resistance genes were found at various levels. As stated in the literature on this subject, there are various differences between countries even in relation to the structures of resistance genes. ${ }^{[30]}$ In a study conducted in Norway, the mef A gene found in S. pyogenes was observed to differ from that found in S. pneumonia, and this gene was noted to have many subtypes. ${ }^{[31]}$ In another Norwegian study, it was stated that the erm (TR) gene was present in 26 of 44 erythromycin-resistant strains, erm (B) or erm (TR) in six, and mef $(\mathrm{E})$ in one. ${ }^{[32]}$ Resistance genes, mechanisms and increased resistance in $S$. pyogenes, as in all bacteria, cause great economic and moral losses across the world. According to the European Centre for Disease Prevention and Control reports, millions of liras are spent every year for this infection, which easily spreads among children and often requires antibiotic treatment. ${ }^{[33]}$ Nevertheless, there are yet-to-be-proven efficacy problems concerning the first treatment option, penicillin, while at the same time, macrolides, one of the primary alternatives, is also becoming more resistant with each passing day. ${ }^{[34]}$ 


\section{CONCLUSION}

The results of our study showed the presence of various resistance genes. When the anamnesis of these patients examined, they were seen to represent a pediatric group that visited the hospital due to frequent, long-lasting throat infections and experienced re-infection within a few weeks after receiving treatment. Similarly, due to their reduced susceptibility, macrolides can occasionally be inadequate in eradicating this infection, which seems simple but incurs serious health-related cost across the world. Further comprehensive studies are required to initiate radical changes in the approach of countries to throat infections. Our study should be supported by new antibiotics resistance studies designed for this purpose and open to development

\section{ETHICAL DECLARATIONS}

Ethics Committee Approval: The study permit was obtained from "Kafkas University, Faculty of Medicine Ethics Board with the decision dated 25.04.2018 and numbered 80576354-050-99.

Informed Consent: Written consent was obtained from all patients who participated in the study and their relatives.

Referee Evaluation Process: Externally peer-reviewed.

Conflict of Interest Statement: The author(s) declared no potential conflicts of interest with respect to the research, authorship, and/or publication of this article.

Financial Disclosure: This study was financially supported by the Scientific Research Projects Unit of Kafkas University, with the project number 2018-TS-67.

Author Contributions: All of the authors declare that they have all participated in the design, execution, and analysis of the paper, and that they have approved the final version.

\section{REFERENCES}

1. Ferretti J, Köhler W. History of streptococcal research. In: Ferretti J, Stevens DL, Fischetti VA, editors. Streptococcus pyogenes: basic biology to clinical manifestations. Oklahoma: The University of Oklahoma Health Sciences Center; 2016.

2. Chu HY, Englund JA. Maternal immunization. Clin Infect Dis 2014;59(4): 560-8.

3. Othman AM, Assayaghi RM, Al-Shami HZ. Asymptomatic carriage of Streptococcus pyogenes among school children in Sana'a city, Yemen. BMC Research Notes 2019;12:339.

4. Steer AC, Carapetis JR, Dale JB et al. Status of research and development of vaccines for Streptococcus pyogenes. Vaccine 2016;34(26): 2953-58.

5. Musser JM, Beres SB, Zhu L et al. Reduced In Vitro Susceptibility of Streptococcus pyogenes to $\beta$-Lactam Antibiotics Associated with Mutations in the pbp2x Gene Is Geographically Widespread. J Clin Microbiol 2020;58(4): e01993-19.

6. Passali D, Lauriello, M, Passali, GC, Bellussi L. Group A streptococcus and its antibiotic resistance. Acta Otorhinolaryngol Ital 2007;27: 27-32.

7. Bley $C$, van der Linden $M$, Reinert RR. mef(A) is the predominant macrolide resistance determinant in Streptococcus pneumoniae and Streptococcus pyogenes in Germany. Int J Antimicrob Agents 2011;37(5): 425-31.
8. Topkaya AE, Balıkçı A, Aydın $F$ et al. Epidemiology, clinical and microbiological characteristics of invasive streptococcal infections in Turkey, 2010-2011. Mikrobiyol Bul 2014;48(1):1-13.

9. Gröndal H. Harmless friendly and lethal: Antibiotic misuse in relation to the unpredictable bacterium Group A streptococcus. Sociology of Health \& Illness 2018;40(7):1127-41.

10. Hansen SM, Uldbjerg N, Kilian M, Uffe B, Sørensen S. Dynamics of Streptococcus agalactiae colonization in women during and after pregnancy and in their infants. J Clin Microbiol 2004;42: 83-9.

11. Bauer AW, Kirby WMM, Sherris JC, Turck M. Antibiotic susceptibility testing by a standardized disk method. Am J Clin Path 1966;45:493-6.

12. Gaertig J, Thatcher TH, Gu L, Gorovsky MA. Electroporation-mediated replacement of a positively and negatively selectable $\beta$-tubulin gene in Tetrahymena thermophile. Proc Natl Acad Sci 1994; 91(10): 4549-53.

13. Sağıroğlu P, Aksu B, Hasdemir MU. Investigation of macrolide resistance mechanisms in Streptococcus pneumoniae: results of Marmara University hospital between 2005-2008. Marmara Med J 2011;24:15-20.

14. 14.https://www.eucast.org/fileadmin/src/media/PDFs/EUCAST_files/ Breakpoint_tables/v 10.0_Breakpoint_Tables.pdf

15. Hammond-Collins K, Strauss B, Barnes K et al. Group A streptococcus outbreak in a canadian armed forces training facility. Military medicine 2019;184(3-4):197-204.

16. Dewyer A, Scheel A, Webel AR, et al. Prevalence of group A $\beta$-hemolytic streptococcal throat carriage and prospective pilot surveillance of streptococcal sore throat in Ugandan school children. Int J Infect Dis 2020;93:245-51.

17. Hanage William P, Samuel A. Shelburne III. "Streptococcus pyogenes with reduced susceptibility to $\beta$-lactams: how big an alarm bell ?. " Clin Infect Dis 2020;71(1):205-6.

18. Kim KS, Kaplan EL. Association of penicillin tolerance with failure to eradicate group A streptococci from patients with pharyngitis. J Pediatr 1985;107(5):681-4.

19.Dicuonzo G, Fiscarelli E, Gherardi G et al. Erythromycin-resistant pharyngeal isolates of Streptococcus pyogenes recovered in Italy. Antimicrob Agents Chemother 2002;46:3987-90.

20. Dundar D, Sayan M, Tamer G. Macrolide and tetracycline resistance and emm type distribution of Streptococcus pyogenes isolates recovered from Turkish patients. Microbial Drug 2010;16(4):279-84.

21. Lu B, Fang Y, Fan Y, et al (2017). High Prevalence of Macrolide-resistance and Molecular Characterization of Streptococcus pyogenes Isolates Circulating in China from 2009 to 2016. Front Microbiol 2017;8(8):1052.

22. Bingen E, Fitoussi F, Doit C et al. Resistance to macrolides in Streptococcus pyogenes in France in pediatric patients. Antimicrob agents chemother 2000;44(6):1453-7.

23. Bozdogan B, Appelbaum PC, Kelly LM et al. Activity of telithromycin compared with seven other agentsagainst 1039 Streptococcus pyogenes pediatric isolates from ten centers in central and eastern. Europe Clin Microbiol Infect 2003;9(7):741-5.

24. Oryaşın E, Bıyık HH, Tristram S, Bozdoğan B. Cloned ermTR gene confers low level Erythromycin but high level Clindamycin resistance in Streptococcus pyogenes NZ131. Microbial Drug Resistance 2020;26(7):747-51.

25. Camara M, Dieng A, Boye C. Antibiotic susceptibility of Streptococcus pyogenes isolated from respiratory tract infections in Dakar, Senegal. Microbiol 2013;6:71-5.

26. Samir A, Abdel-Moein KA, Zaher HM. Emergence of penicillin-macrolideresistant Streptococcus pyogenes among pet animals: An ongoing public health threat. Comp Immunol Microbiol Infect Dis 2020; 68:101390.

27. Dundar D, Sayan M, Tamer G. Macrolide and tetracycline resistance and emm type distribution of Streptococcus pyogenes isolates recovered from Turkishpatient. Microb Drug Resist 2010;16(4):279-84.

28. Bley C, van der Linden $M$, Reinert RR. mef(A) is the predominant macrolide resistance determinant in Streptococcus pneumoniae and Streptococcus pyogenes in Germany. J Antimicrob Agents 2011;37(5):425-31.

29. Vannice KS, Ricaldi J, Nanduri $S$ et al. Streptococcus pyogenes pbp $2 x$ Mutation Confers Reduced Susceptibility to $\beta$-lactam antibiotics. Clin Infect Dis 2020;71(1): 201-4. 
30. Öztop AY, Şanlıdağ T, Erandaç, M. Grouping and Determining of Antibiotic Susceptibilty of Beta-Haemolytic Streptococci Isolated from Children with Upper Respiratory Tract Infection. Turk Mikrobiyol Cem Derg 1999;30:73-6.

31. Sangvik M, Littauer P, Simonsen GS, Arnfinn S, Kristin HD. mef(A), mef(E) and a new mef allele in macrolide-resistant Streptococcus spp. İsolates from Norway, J Antimicrob Chemother 2005;56(5):841-6.

32. Littauer P, Caugant DA, Sangvik M, Høiby EA, Sundsfjord A, Simonsen GS. Macrolide-resistant Streptococcus pyogenes in Norway: population structure and resistance determinants, Antimicrob Agents Chemother 2006; 50(5):1896-99.

33. https://www.ecdc.europa.eu/en/search?s=cost+of+resistant+bacterias (accession date 14.01.2021)

34. Fitoussi F, Loukil C, Gros I et al. Mechanisms of macrolide resistance in clinical group B streptococci isolated in France. Antimicrob Agents Chemother 2001; 45:1889-91. 